Published in the Journal for the Scientific Study of Religion (2014)

Vol. 53, Issue 3, 479-496

DOI: $10.1111 /$ jssr. 12130

\title{
Male and Female $\mathrm{He}$ Created Them: Gender Traditionalism, Masculine Images of God, and Attitudes toward Same-Sex Unions
}

Prior research demonstrates that religion and gender traditionalism are associated with less favorable attitudes toward same-sex unions because of its deviation from customary religious doctrine and traditional patterns of gender behavior. Using a national random sample of American adults, this study examines the link between religion, gender traditionalism, and attitudes toward same-sex unions by utilizing a novel measure of gender traditionalism that is distinctly religious as well. Recent work on images of God reveals that individuals' views of the divine provide a glimpse of their underlying view of reality. The results suggest that individuals who view God as a "he" are much less favorable toward same-sex unions than those who do not view God as masculine, even while controlling for gender traditionalist beliefs and other images of God. Individuals who view God as masculine are signaling a belief in an underlying gendered reality that influences their perceptions of the proper ordering of that reality, which extends to marriage patterns. These findings encourage future research to identify innovative measures of religion that incorporate aspects of other social institutions to account for their interconnected nature.

Keywords: Religion, Gender, Same-Sex Marriage, Images of God, United States, Homosexuality

Andrew L. Whitehead Assistant Professor Clemson University alw6@clemson.edu 
It is now no secret that in the general population attitudes toward homosexuality and same-sex unions are more favorable than in the past (Andersen and Fetner 2008; Sherkat et al. 2011). The Stonewall riots in 1969 and the rise of the Religious Right through the 1980s thrust homosexuality into the public discourse, the political sphere, and the consciousness of millions of Americans (Fetner 2008). Recent political and legal struggles over the rights of gay men and lesbians showcase the ongoing salience of this issue. In the summer of 2013 the United States Supreme Court overturned the Defense of Marriage Act (DOMA) and California's now famous Proposition 8. However, recent data show that Americans are still basically split in their opinions on gay marriage. The 2012 General Social Survey reports that 48.9 percent of Americans agree or strongly agree that gays and lesbians should be allowed to marry, while 39.1 percent of Americans disagree or strongly disagree with gay marriage.

Due to the ongoing and very public nature of the fight over equality for lesbians and gays, attitudes toward same-sex unions continue to warrant investigation. Prior research points to the importance of gender traditionalism and religion when predicting attitudes toward gays and lesbians. Individuals with traditional gender beliefs view homosexuality negatively because they see it as an attack on the traditional family and the proper roles for men and women in society (Brewer and Wilcox 2005; Brumbaugh et al. 2008; Burdette, Ellison, and Hill 2005; Herek 1986, 2002; Hill, Moulton, and Burdette 2004; Kite and Whitley 1996; Wald, Button, and Rienzo 1996). Religious individuals tend to oppose homosexuality due to their interpretation of sacred texts and the historical teachings for particular religious traditions (Burdette et al. 2005; Froese, Bader, and Smith 2008; Olson, Cadge, and Harrison 2006; Sherkat et al. 2011; Whitehead 2010). To date, however, there have been no attempts to utilize measures that incorporate aspects of both gender and religion. 
Operationalizing religious gender traditionalism using a measure which is novel to the literature, I find evidence that those individuals who hold a masculine image of God are much more likely to oppose same-sex unions. This finding is important theoretically for a number of reasons. First, the present study encourages future research to utilize measures that incorporate aspects of different social institutions, in this case gender and religion, as no institution is completely separate from others (Martin 2004). Social institutions are in many ways intertwined with one another and "assuming any institution is separate from others produces flawed understanding" (Martin 2004:1258). Measuring the interconnectedness of religion as a social institution with other social institutions like gender will allow future examinations to account for distinct aspects of routine concepts. This is important concerning a topic like attitudes toward same-sex unions because no prior study in the literature accounts for the effects of religion and gender traditionalism simultaneously.

Second, it highlights the need for expanding and diversifying how religious belief is measured to provide texture and depth to how religion is related to various attitudes. Prior research highlights the importance of images of God. However, there has been little broadening of the images of God researchers utilize, especially concerning issues where varying social institutions, like religion, gender, and sexuality, intersect. Broadening the types of God-images used, and specifying why these images should in theory be linked to the topic under examination, allows researchers to speak to the importance of religion across various sub-fields of social scientific inquiry. Finally, the findings themselves indicate that due to religious individuals' gendered views of reality we can expect continued opposition even though the attitudes of the wider culture toward same-sex unions are continuing to liberalize. Religion, Gender Traditionalism, and Attitudes toward Homosexuality 
Religious affiliation, belief, and behavior are commonly associated with individuals' attitudes toward gender roles and homosexuality. While some religious individuals and groups are thoroughly egalitarian in their view of gender roles, more often than not religion is associated with a conservative gender ideology (Bang et al. 2005; Denton 2004; Read and Bartkowski 2000). Regarding religious affiliation, Conservative Protestant groups are more likely to hold very traditional views of the roles for men and women (Bang et al. 2005; Bartkowski 2001; Denton 2004; Gallagher 2003). Those holding traditional religious beliefs and who hold their holy scriptures in high regard are also more likely to espouse traditional gender ideologies (Denton 2004; Hoffmann and Bartkowski 2008). Religious behavior is also associated with gender-role views. High levels of religious practice are associated with more traditional genderrole beliefs (Ammons and Edgell 2007).

Turning to attitudes toward homosexuality, those who identify with an Evangelical or Black Protestant denomination are usually the most unfavorable toward homosexuality (Andersen and Fetner 2008; Hill et al. 2004; Whitehead 2013) and same-sex unions (Olson et al. 2006; Sherkat et al. 2010; Sherkat et al. 2011; Whitehead 2010) with Catholic, Mainline Protestant, and Jewish individuals reporting more favorable attitudes toward homosexuality generally and same-sex unions in particular. Individuals who hold traditional religious beliefs are typically unfavorable toward gays and lesbians (Burdette et al. 2005; Froese et al. 2008; Hill et al. 2004; Sherkat et al. 2010; Sherkat et al. 2011; Whitehead and Baker 2012; Whitley 2009). Finally, individuals who exhibit higher levels of religious practice are likely to hold unfavorable 
views of homosexuality (Andersen and Fetner 2008; Burdette et al. 2005; Hill et al. 2004; Olson et al. 2006; Sherkat et al. 2010; Whitehead 2010; Whitley 2009). ${ }^{1}$

Beyond the association of religion with gender traditionalism and attitudes toward homosexuality, gender traditionalism itself is closely associated with attitudes toward homosexuality. Individuals (both men and women) holding more traditional gender beliefs are generally unfavorable toward lesbian, gay, bisexual, and transgendered (LGBT) persons (Kite and Whitley 1996; LaMar and Kite 1998; Sakalli 2002; Sirin, McCreary, and Mahalik 2004; Whitley 2001; Whitley and Ægisdóttir 2000). Gender traditionalists view gay men and lesbians negatively because they are believed to exhibit traits commonly associated with the opposite sex. Gay men are viewed as less masculine and more feminine while lesbians are believed to be less feminine and more masculine (Blashill and Powlishta 2009; Sirin et al. 2004; Whitley 2001). This form of stereotyping, labeled the Gender Belief System Perspective, anticipates others will fit into a relatively stable set of roles and traits where people are either fully masculine or feminine. Therefore, same-sex unions pose an especially strong threat and gay men and lesbians are viewed negatively (Kite and Whitley 1996, 1998; Whitley and Ægisdóttir 2000).

Another reason same-sex unions elicit negative reactions is due to how traditional gender beliefs are intimately tied to another value commonly held in high regard in the United States: the traditional, nuclear family (Brewer and Wilcox 2005; Brumbaugh et al. 2008; Burdette et al. 2005; Hill et al. 2004; Wald et al. 1996). A marked division of labor and authority between the sexes is often present within the idea of the "traditional family" that most religious groups hold as the ideal (Wald et al. 1996). Individuals with a traditional view of marriage deem it the foundation of a stable society where altruistic norms and civic skills are instilled in the next

\footnotetext{
${ }^{1}$ It is important to note that even among religious individuals attitudes toward various aspects of homosexuality are not uniform. While they tend to strongly oppose gay marriage, there is relatively little opposition toward equal employment opportunities for gays and lesbians, or their right to secure adequate housing.
} 
generation (Eskridge and Spedale 2006). Because homosexuality is an alternative to the traditional understanding of family, proponents of traditional marriage view same-sex relationships as a severe threat to the institution of marriage and thus a threat to a functioning, stable social order (Hill et al. 2004; McVeigh and Diaz 2009; Wald et al. 1996). Individuals' feelings about the vulnerability of heterosexual marriage is an extremely important predictor of attitudes toward homosexuality generally, and same-sex marriage in particular (Brumbaugh et al. 2008). Procreation is also considered a central aspect of traditional views of marriage (Burdette et al. 2005) and is highlighted by many religious individuals as a divine mandate. For instance, the Christian tradition points to Genesis 1:28: "God blessed them; and God said to them, 'Be fruitful and multiply, and fill the earth,"” (NASB 1995). Because gay men and lesbians cannot procreate their unions are considered something altogether different from traditional marriage.

Additionally, it is within marriage that gender traditionalists believe the proper roles for men and women are acted out. In same-sex unions, gender traditionalists believe that gay men are relinquishing the advantaged status of being male (Herek 2002; Kite and Whitley 1998; LaMar and Kite 1998). The male role is generally perceived as one of higher status in American society compared to the female role (Bem 1993) and so attempts to abandon that status must not be tolerated (Herek 1986). Religion serves to accentuate the perception that manhood is an advantaged status in the ordering of the universe (Daly 1985; Gallagher 2003). Men usually are less tolerant of other men who they perceive as having "given up" the advantageous male role (Herek 1986, 2002; Kite and Whitley 1996, 1998). While past research has focused on the more negative reaction males receive, for some groups, women abdicating their female role might be just as intolerable. Some conservative Christian groups idealize women in traditional female roles (Gallagher 2003). This form of benevolent sexism places women on a pedestal, recognizes 
men's dependence on them, and believes that men are not "complete" until each has a woman. This type of sexism is predictive of more negative attitudes toward homosexuality as well (Sakalli 2002). Therefore, individuals with traditional views of gender are more likely to oppose homosexuality and same-sex unions because in those unions the preferred roles for men and women are abandoned.

While prior research demonstrates relationships between a) religion and gender traditionalism, b) religion and same-sex union attitudes, and c) gender traditionalism and attitudes toward homosexuality (but not same-sex unions in particular), no prior study examines these relationships collectively, resulting in a significant gap in need of analysis. In order to fill this gap, the present study examines attitudes toward same-sex unions while 1) accounting for the effect of traditional gender beliefs, and 2) proposing a novel measure of gender traditionalism that is distinctly religious as well: the degree to which individuals believe God is masculine. Images of God, Gender Traditionalism, and Attitudes toward Homosexuality

A vibrant body of research contends that how individuals view God is closely associated with an assortment of important outcomes. Views of a controlling God can influence individuals' sense of mattering, psychological distress, and their sense of personal control (Schieman 2008; Schieman, Bierman, and Ellison 2010). A “Loving” image of God is also found to influence individuals' sense of meaning in life, trust of others, civic engagement, and support of capital punishment (Mencken, Bader, and Embry 2009; Ozorak 2003; Stroope, Draper, and Whitehead 2013; Unnever, Cullen, and Bartkowski 2006). Viewing God as actively involved in the world or judgmental of it can influence beliefs about economic outcomes, moral absolutism, abortion attitudes, mental health, and various political views (Bader et al. 2010; Froese and Bader 2007, 2008, 2010; Froese et al. 2008; Schieman and Jung 2012; Silton, et al. 2013; Whitehead 2010). 
An "Active" view of God means believers hold that God is intimately involved with the happenings of not only the world, but their daily lives as well. God can at times intervene to not only save someone from harm, but possibly even provide a parking space. An "Angry" view of God refers to how judgmental a believer finds God to be. God may be upset with the world as a whole, or with the very particular sins of individuals. At times, God may even send natural disasters or personal troubles to alert an individual or nation of their shortcomings. Some research utilizes a measure of how controlling believers view God to be. Among each of the various images of God used in past research, Froese and Bader (2007) argue that the extent to which someone believes God is actively involved in the world and judgmental of it are most predictive of believers' attitudes and behaviors, especially their attitudes toward same-sex unions and homosexuality (Froese and Bader 2008, 2010; Froese et al. 2008). It is important to note, though, that none of these analyses control for traditional gender role beliefs.

Researchers contend that images of God are valuable because they allow for observation of individuals' underlying philosophical and moral worldviews which they may have difficulty verbalizing (Froese and Bader 2010:147). They let researchers appreciate to a fuller extent what is undergirding and perhaps motivating people's beliefs, attitudes, and actions. God, however conceptualized, operates as a generalized other that becomes not only an object of contemplation but also interaction (Berger 1969; Froese and Bader 2010). In fact, as Berger (1969:38) points out, God in many ways can become someone's "most reliable and ultimately significant other." As Froese and Bader highlight, people often ask themselves, "What will God think? How would God respond to this? Which path does God want me to follow?" (2010:9-10). Knowing the form this "ultimate generalized other" takes provides insight into why and how people answer those questions the way that they do. 
However, when that "ultimate generalized other" is perceived to be gendered in some way the legitimation of certain social institutions, like proper roles for men and women, takes on added significance. Prior research on images of God and attitudes toward same-sex unions neglects the role of traditional gender ideology on these attitudes. A number of feminist theologians point out the pervasive influence that a gendered view of God can have on a society through legitimating certain structural arrangements and gender ideologies (Christ 1987; Daly 1973, 1985; Lindsey 1990; Morton 1985; Stone 1976). Due to the hegemony of Judeo-Christian religions in the United States, these theologians focus their attention on the negative effects of viewing God as masculine. However, perceiving God as feminine does influence individuals' worldviews. Greeley $(1988,1993)$ shows that individuals who view God as "motherly" are more likely to care for the environment and be politically liberal.

Those who perceive God to be masculine (as is most common in the United States), alternatively, are signaling an underlying belief that there is a masculine-gendered nature to all of reality and that there are strict roles into which men and women must fit (Gallagher 2003). Whitehead (2012a) provides quantitative evidence of this association, that those who believe God is masculine also hold very traditional views of gender roles. Individuals who ascribe to a masculine image of God are much more likely to espouse traditional gender ideologies to those who do not view God as masculine. ${ }^{2}$ In theory there are several reasons why a masculine image of God should predict opposition toward same-sex unions.

First, because a masculine image of God signals an underlying belief that there is a gendered nature to all reality, anything that threatens the fulfillment of the "proper" roles for men and women in family life is undesirable. Because God is masculine, and men are a direct

\footnotetext{
${ }^{2}$ The traditional gender ideologies referenced in this work include believing men are better suited for politics, children are harmed when their mother works, it is God's will that women care for children, and that men should earn more than women, especially within families.
} 
representation of God and so receive a certain amount of authority in family life, women are to submit to that authority. Therefore, same-sex unions clash with this understanding of the "traditional" family and threaten a stable social order which should, again, comply with the underlying gendered nature of all reality (Hill et al. 2004; McVeigh and Diaz 2009; Wald et al. 1996). Second, and more broadly, because belief in a masculine God signals an adherence to particular hierarchical roles for men and women, anyone who relinquishes those roles is bound to be judged harshly. Men are believed to occupy an advantageous role in society and the family and to abdicate that position is not tolerated (Herek 1986). Likewise, women abandoning their role as faithful supporters of men are just as intolerable to some groups (Gallagher 2003). Relationships outside of the heterosexual ideal violate these roles and are subsequently opposed.

Finally, many believe that America was founded under God's direction and blessing and that God's protection and blessing can be lost if America strays too far from the morals upon which it was founded (Bellah 1975; Wald and Calhoun-Brown 2007). The traditional family is recognized as a vital piece of the founding morals of the United States and many religious individuals believe that abandoning traditional gender beliefs leads to the breakdown of the traditional family. This in turn results in societal disintegration which will cause God to cease blessing the United States and let it fail. Believing God is a "he" changes the complexion of believing that the United States maintains a covenantal relationship with God. It is now not just that God decrees families should operate in a particular way or that a man's and woman's role should take on a certain form, it is rather that God's nature, in and of itself, is proof of why the traditional family is the ideal and same-sex unions should be opposed. Those who hold a masculine God believe that if families and men and women in the United States begin to depart 
from their correct gendered manifestations, the masculine God who has blessed the United States in centuries past will turn his back on it once and for all.

Therefore, this study proposes the following hypotheses:

H1: More masculine views of God will be significantly associated with less support for same-sex civil unions net of the effects of traditional gender role beliefs, believing God is actively involved in the world, and believing God is judgmental of it.

H2: More masculine views of God will be significantly associated with less support for same-sex marriage net of the effects of traditional gender role beliefs, believing God is actively involved in the world, and believing God is judgmental of it.

Data

Data for this study are drawn from the second wave (2007) of the Baylor Religion Survey (BRS). The 2007 BRS is a random, national sample of 1,648 U.S. citizens administered by the Gallup Organization. The survey utilized a mixed-mode sampling design consisting of two phases. A total of 3,500 individuals were screened (1,000 in phase $1+2,500$ in phase 2$)$ with 2,460 possible respondents (624 from phase $1+1,836$ from phase 2 ). A total of 1,648 questionnaires were returned resulting in a response rate of $47 \%(1,648 / 3,500)$ among all individuals screened and a response rate of $67 \%(1,648 / 2,460)$ for those who agreed to receive a mailed survey. This response rate is within the normal parameters for random-digit dialing samples (see Froese and Bader 2010). The 2007 BRS is ideal because it contains measures of attitudes toward homosexuality, gender traditionalism, and masculine images of God in addition to a breadth of socio-demographic and religion variables known to influence attitudes toward homosexuality.

Dependent Variables 
The dependent variables used in this investigation ask for respondents' views on both same-sex marriage and civil unions. The two questions ask: "Homosexuals should be allowed to marry," and "Homosexuals should be allowed civil unions." 3 Possible responses range from "Strongly Agree" to "Strongly Disagree." Each measure was dichotomized so that "Strongly Agree" and "Agree” equal one (See Table 1).

\section{Independent Variable of Interest}

The key independent variable of interest is the level to which individuals view God as masculine or not. ${ }^{4}$ Respondents to the survey were asked for their level of agreement $(1=$ Strongly Disagree to 5 = Strongly Agree) with the statement: "Based on your personal understanding, what do you think God is like: A 'He." The mean is 3.35 with a standard deviation of 1.32 (see Table 1).

\section{Key Control Variables}

The three key control variables for this analysis are two images of God indexes and a gender traditionalist index. The traditional gender-role beliefs index measures respondents' attitudes toward the proper roles for women and men in society. The index is comprised of four

\footnotetext{
${ }^{3}$ One weakness of the measures used is that they ask for respondents' attitudes toward "homosexuals" rather than delineating between attitudes toward gay men and lesbians. Attitudes toward gay men and lesbians are usually conflated when asking for responses to "homosexuality" leading the stronger negative reaction toward gay men to overwhelm the sometimes less negative reaction toward lesbians. This results in more negative reactions to homosexuality generally compared to attitudes toward lesbians (Herek 2002; Kite and Whitley 1996; Sirin et al. 2004). While appeals to measure attitudes toward gay men and lesbians separately is common in psychological studies utilizing convenience samples of college students (e.g. Herek 2002; Kite and Whitley 1996; Whitley 2009), Herek (2002) points out that public rhetoric commonly utilizes "homosexuality" without distinguishing between gay men and lesbians. Furthermore, many opposing movements condemn homosexuality for both men and women while the gay movement desires equality for gay men and lesbians. Therefore, in the public discourse lesbians and gay men share a "common characteristic that makes them members of a distinct quasi-ethnic group with its own culture and political concerns" (Herek 2002:42). This suggests that while the present scale cannot distinguish between attitudes toward lesbians and gay men, it does tap into the broader set of attitudes maintained by a majority of the public.

${ }^{4}$ While there are many possible gendered views of God (masculine, feminine, androgynous) this study focuses on the masculine view of God for two reasons. First, feminist theologians believe the masculine God image to be most damaging to society as a whole. Second, as feminist theologians also point out, the masculine image of God is pervasive throughout the major religious traditions operating in the United States, as well as in the culture generally (see Christ 1987).
} 
items that ask for respondents' level of agreement $(1=$ Strongly Disagree to $5=$ Strongly Agree $)$ to the following statements: "Most men are better suited emotionally for politics than most women," "A preschool child is likely to suffer if his or her mother works," "It is God's will that women care for children," and "A husband should earn a larger salary than his wife." These items are widely used when constructing gender ideology indexes (see Davis and Greenstein 2009). The alpha reliability coefficient for the index is 0.74 . The gender-role traditionalism index ranges from 4 to 20 . The mean value for the index is 9.95 with a standard deviation of 3.69 (see Table 1). Higher scores on the index equate to more traditional gender-role beliefs.

The other key control variables are two widely used images of God indexes that measure the extent to which respondents' view God as active in the world and judgmental of it (Bader et al. 2010; Froese and Bader 2007, 2008, 2010; Schieman and Jung 2012; Silton, et al. 2013; Whitehead 2010). The active view of God index is comprised of seven different questions where higher scores represent a view of God as active in the world. The questions include: "Is God 'removed from worldly affairs', 'concerned with the well-being of the world', 'concerned with my personal well-being', 'directly involved with worldly affairs', and 'directly involved in my affairs"” with possible responses ranging from "Strongly Disagree" to "Strongly Agree". Two additional questions ask if the adjectives "ever-present" or "distant" describe God and possible responses range from "Very Well" to "Not at All." Each of these questions was flipped as needed and summed to create the active view of God scale. The alpha reliability coefficient for the index is 0.88 and with a range from 7 to 35 . The mean is 26.51 with a standard deviation of 6.72 (See Table 1).

The angry view of God index is constructed using the questions "Is God 'angered by human sin,' or 'angered by my sin,"” (“Strongly Agree" to "Strongly Disagree”) and how well 
the words "critical," "punishing," "severe," and "wrathful” describe God ("Very Well” to "Not at All”). These six questions were flipped as needed where higher scores equate to a more wrathful, angry, or judgmental view of God. The alpha reliability coefficient for this index is 0.85 with a range of 6 to 30 . The mean is 16.55 with a standard deviation of 6.28 (See Table 1).

[Table 1 about here]

\section{Control Variables}

Building upon past research analyzing attitudes toward homosexuality, the study includes a host of socio-demographic and religion variables. Demographic variables are age (in years), gender $(1=$ Female $)$, income $(1=\$ 10,000$ or less to $7=\$ 150,000$ or more $)$, education $\left(1=8^{\text {th }}\right.$ grade or less to $7=$ postgraduate work/degree $)$, political ideology $(1=$ Extremely Liberal to $7=$ Extremely Conservative), race $(1=$ White $)$, region $(1=$ South $)$, marital status $(1=$ Married $)$, and whether homosexuality is innate $(1=$ Homosexuality innate). Each exhibited a significant association with attitudes toward homosexuality in past research (Andersen and Fetner 2008; Brumbaugh et al. 2008; McVeigh and Diaz 2009; Olson et al. 2006; Sherkat et al. 2010; Sherkat et al. 2011; Whitehead 2010).

Religious affiliation, belief, and behavior are additional control variables associated with individuals' attitudes toward homosexuality in previous studies. Religious affiliation is measured using the RELTRAD typology which categorizes individuals into seven religious traditions: Evangelical Protestant, Mainline Protestant, Catholic, Jew, Black Protestant, other, and no religion (Steensland et al. 2000). ${ }^{5}$ Evangelical Protestants will serve as the contrast category because they consistently hold the most unfavorable attitudes toward homosexuality.

\footnotetext{
${ }^{5}$ For details about religious tradition coding in the Baylor Religion Survey, see Dougherty, Johnson and Polson (2007).
} 
A common measure of traditional religious beliefs is whether the respondent interprets the Bible in a literal manner. A question in the 2007 BRS asked, "Which one statement comes closest to your personal beliefs about the Bible?" Possible responses were "The Bible means exactly what it says. It should be taken literally, word-for-word, on all subjects;" "The Bible is perfectly true, but it should not be taken literally, word-for-word. We must interpret its meaning;" "The Bible contains some human error;" and "The Bible is an ancient book of history and legends." This measure was dichotomized so that those answering that the Bible should be read literally, word-for-word were coded as a one with all other responses coded as a zero.

To measure religious behavior the analysis includes an index that combines religious service attendance, frequency of prayer/meditation, and frequency of reading sacred scriptures. The items for attendance and scripture reading range from $1=$ Never to $9=$ Several times a week. The item measuring prayer frequency ranges from $1=$ Never to $6=$ Several times a day. Factor analysis revealed that these measures of religious behavior load onto the same factor, with factor loadings all above 0.85 . Each measure was standardized and then summed due to unit measurement differences across questions. The alpha reliability coefficient for the index is 0.84 . A benefit of the index is that it measures multiple forms of religious practice rather than only focusing on frequency of attendance which for different traditions can vary in meaning.

\section{Methodology}

Table 1 reports the descriptive statistics and bivariate associations between all of the independent variables and the two dependent variables. Tables 2 and 3 display the multivariate analyses for attitudes toward same-sex civil unions and same-sex marriage respectively. Logistic regression is utilized due to the coding of the dependent variables. Multivariate analysis proceeds in four steps for each dependent variable. The first model in Tables 2 and 3 displays all 
of the control variables without the masculine image of God measure. Model 2 includes the masculine image of God measure with the socio-demographic and religion controls. Model 3 includes the traditional gender-role beliefs index and the masculine image of God measure without the other image of God measures. Model 4 includes the masculine image of God measure and the two images of God measures while excluding the traditional gender-role beliefs index. Model 5 presents the full model with the traditional gender-role beliefs index, the two other images of God measures, and the masculine image of God measure. Moving from model 1 to model 5 allows examination of the relationships between the independent variable of interest, the key control variables, and the dependent variables net of the effects of each of the control variables. ${ }^{6}$ All of the variables included in the final models except religious tradition and region had missing information. Multiple imputation (MI) was used to correct for missing data (Rubin 1987, 1996). ${ }^{7}$ To allow for the interpretation of substantive significance alongside statistical significance, standardized coefficients for the logistic regression models were estimated $\left[B_{y x}^{*}=\right.$ $\left.b_{y x}\left(s_{x} / s_{y}\right)\right]$ (Pampel 2000). ${ }^{8}$ Finally, the predicted probabilities of supporting civil unions and marriage at the different levels of the masculine God measure were computed and Figure 1 graphically displays those outcomes. ${ }^{9}$

Results

\footnotetext{
${ }^{6}$ A number of interactions between the masculine image of God measure, the gender traditionalism scale, and the other image of God scales were also examined. None reached statistical significance $(\mathrm{p}<.05)$ and as such are not included in this analysis.

${ }^{7}$ The MI procedure generates five imputations using multiple Markov Chains based on all variables included in each model, resulting in an overall $\mathrm{N}$ of 8,240 (1,648 X 5). All results use the MI dataset. The correlations reported in Table 1 and all of the results reported in Tables 2 and 3 are from the MIANALYZE procedure in SAS. This procedure combines all of the results from each of the five imputations resulting in overall estimates, standard errors, and significance levels. The standardized coefficients and odds ratios for each model were calculated using these overall estimates. The Proportional Reduction in Error (PRE) reported in Tables 2 and 3 for each model are the average of the PRE for each individual iteration.

8 This analysis follows Pampel's (2000) assumption that the standard deviation of logit $(\mathrm{y})=1.8138$.

9 The predicted probabilities hold all significant effects from each dependent variable's full model at their means.
} 
Table 1 displays the bivariate correlations between the dependent variables and the independent variable of interest and the key control variables. Viewing God as a "he" is strongly correlated with negative attitudes toward both civil unions $(-0.43 ; \mathrm{p}<.001)$ and marriage $(-0.43$; $\mathrm{p}<.001)$. However, the traditional gender-role beliefs index and the two images of God measures are also strongly correlated with negative attitudes toward civil unions and marriage (see Table 1).

Table 2 contains the results for the civil union multivariate regression models. Model 1 displays the results for the control variables. Model 2 employs the masculine image of God measure alongside the socio-demographic and religion control variables. Viewing God as a "he" is significantly and negatively associated with support for same-sex civil unions net of all other effects. In model 3 the masculine image of God measure is still significantly associated with more negative views of civil unions and the gender role index is significant and negative in its association as well. In model 4 the masculine image of God measure maintains its significant and negative association with support for civil unions despite the inclusion of the two images of God measures. The "Angry" God index is the only one that is significantly associated with the dependent variable. In model 5 the full model is displayed. Viewing God as a "he" is significantly and negatively associated with support for civil unions net of all the other effects in the full model including various images of God and other traditional gender-role beliefs. With every increase in level of agreement that God is a "he," the odds of supporting same-sex civil unions decrease by 23 percent. ${ }^{10}$ Surprisingly, neither the "Active" nor "Angry" image of God measure achieves statistical significance. The traditional gender-role index is significantly and negatively associated with support for civil unions as are the politically conservative,

\footnotetext{
${ }^{10}$ In order to calculate the percent change in odds for those measures with negative odds ratios 1 is divided by each ratio. This is to correct for their being bounded between 0 and 1 . Therefore, God is a "he" $=1 / 0.81=1.23$.
} 
southerners, biblical literalists, and those who actively practice their religion. Higher levels of income and education predict support for civil unions as does belief that homosexuality is innate.

[Table 2 about here]

The models in Table 3 turn to support for same-sex marriage. Model 1 displays the results for the control variables. In model 2 the masculine image of God measure is significantly and negatively associated with support for same-sex marriage despite the effects of various religion and socio-demographic controls. In model 3 the masculine image of God measure is still significantly and negatively associated with support for same-sex marriage while the traditional gender-role beliefs index is also significantly and negatively associated. In model 4 the masculine image of God measure maintains its significant and negative association despite the inclusion of the other two images of God measures, neither of which achieves statistical significance. All of the variables are included in model 5. Again, viewing God as a "he" is significantly and negatively associated with support for same-sex marriage net of all the other effects in the model including various images of God and other traditional gender-role beliefs. Regarding attitudes toward same-sex unions, each increase in agreement that God is a "he" decreases the odds that respondents will support same-sex marriage by 28 percent. Neither the "Active" nor "Angry" image of God measures achieves statistical significance. The traditional gender-role index is significantly and negatively associated with support for same-sex marriage as are the politically conservative, older adults, and those who actively practice their religion. Belief that homosexuality is innate leads to much more supportive views of same-sex marriage.

\section{[Table 3 about here]}

Figure 1 displays the predicted probabilities of supporting same-sex civil unions and same-sex marriage for different values of the masculine image of God measure. At the lowest 
level of belief that God is a "he," nine out of ten individuals support same-sex civil unions (0.91) while eight in ten individuals who strongly believe God is a "he" support same-sex civil unions (0.81). For same-sex marriage, half of the respondents who do not view God as masculine will offer support (0.51) while only three in ten (0.28) of those who view God as a "he" will do so. For both models the masculine image of God measure exerts a noticeable effect on support for same-sex unions at the mean levels for all of the control variables. It is also apparent that viewing God as masculine has a much more pronounced effect on attitudes toward same-sex marriage (20\% decrease) compared to same-sex civil unions (10\% decrease).

[Figure 1 about here]

\section{Discussion}

The results reported in tables 2 and 3 and figure 1 demonstrate that masculine images of God are consistently significantly associated with less support for same-sex unions. Individuals who view God as masculine are signaling a belief in an underlying gendered reality that influences their perceptions of the proper ordering of that reality (Froese and Bader 2010; Gallagher 2003). Gay men and lesbians are perceived as violating what many believe are the proper ways in which men and women should express themselves in society (Blashill and Powlishta 2009; Kite and Whitley 1996; Whitley and Ægisdóttir 2000). A crucial component of the ordering of reality and the proper roles for men and women appears to be the construction of family life around marriage and to a lesser extent domestic partnerships. As attitudes toward same-sex unions continue to liberalize in the wider culture, continued resistance to that liberalization could be found among those who maintain a view that God is gendered masculine. This would be most important for attitudes toward same-sex marriage, however. While individuals' masculine image of God influences their views of same-sex civil unions net of all 
other effects, it exerts a much stronger effect on attitudes toward same-sex marriage (see Figure 1). Masculine images of God may thus prove to be one explanation as to why religious individuals tend to oppose same-sex marriage much more strongly compared to same-sex civil unions. Those who view God as masculine may prove to be a group particularly resistant to liberalization because viewing God as masculine may exist as an integral part of their overall gendered worldview that extends beyond same-sex marriage issues. No longer viewing God as a "he" would not only mean a shift in attitudes toward same-sex unions but also in how their own marriages, society, or religious groups are ordered.

These findings suggest that because the gendered image of God measure is not just an additional measure of gender traditionalism or religious belief, it is actually a measure of the interrelated aspect of the social institutions of religion and gender. It assesses facets of those two social institutions that were untapped by the measures utilized in past research up until this point. This is an important methodological finding. In her argument encouraging researchers to view gender as a social institution, Patricia Yancey Martin (2004) contends that all social institutions are utterly intertwined. In fact, when researchers assume that any institution is separate from others, they will undoubtedly form an explanation inconsistent with reality (Martin 2004). While prior research did not neglect the interrelated nature of gender and religion as social institutions theoretically, it did partially neglect it methodologically. By simply including separate measures of gender and religion into multivariate models the area of significant overlap between the two was overlooked. Prior studies do not contain measures that explicitly combine aspects of the two social institutions like the gendered image of God measure. Ideally, future research on gender and religion will attempt to construct measures that creatively assess the interrelated nature of these two social institutions. In fact, researchers studying religion should consistently search for 
ways to operationalize the interrelated nature of religion as a social institution with other social institutions like family, gender, sexuality, the economy, or the polity. By doing so we can better explicate the importance of religion in the modern world by identifying not only the ways in which it is intimately related to other social institutions but also how neglecting this fact leads to methodological and theoretical inaccuracies.

The results further show that controlling for gendered images of God is distinct from images of God used in prior research. Past studies demonstrate that viewing God as active in the world or judgmental of it was significantly associated with more negative attitudes toward homosexuality but each of these studies failed to account for the strong effects of gender traditionalism (Froese and Bader 2008, 2010; Froese et al. 2008; Whitehead 2010). When both of these other two images of God were included in the models with the masculine image of God variable, the masculine image of God measure remained significant; the other images of God were non-significant. This suggests that when considering attitudes toward same-sex unions, it is the perceived gendered nature of God that truly matters above and beyond God's perceived level of activity in the world or God's perceived level of judgment of the world. The gendered image of God measure is not merely measuring belief in any sort of God. In fact, when looking at model 1 in table 3 on attitudes toward same-sex marriage neither the active or angry image of God measures found significant in past research are statistically significant when controlling for traditional gender-role beliefs. Such a finding would lead some to believe that images of God may not be important once gender traditionalism is taken into account. In the full model (model 5), we see this is inaccurate; individuals' gendered perceptions of the divine are strongly associated, even when controlling for their traditional gender role beliefs. 
Several limitations of this study must be mentioned. First, due to the cross-sectional nature of the data I cannot determine causal direction. It may be that individuals' attitudes toward homosexuality change their views toward God's perceived gender and the proper roles for men and women in society. Nevertheless, past research supports the theoretical progression identified in this study. For most individuals, gender and religious socialization tend to occur much earlier than the crystallization of same-sex union attitudes. In fact, as discussed earlier, much of the support for either negative or positive views of same-sex unions flows out of particular gender or religious attitudes. Second, the questions used in the construction of the dependent variable conflate attitudes toward gay men and lesbians by asking for responses concerning "homosexuals." Past studies find that attitudes toward gay men and lesbians can vary. As discussed previously (see footnote 3) however, the public rhetoric usually references "homosexuality" without distinguishing between lesbians and gay men. Therefore, this scale does tap into the broader set of attitudes maintained by the wider public. Finally, these data were gathered in 2007 and attitudes toward same-sex unions have changed significantly since then. For example, in this sample 33.6 percent strongly agree or agree that same-sex marriage should be legal while 48.9 percent favor gay marriage according to the 2012 General Social Survey These increases in support are also apparent across religious groups, including Evangelical Protestants. Because of the dramatic shift in attitudes toward same-sex unions since 2007, the results of this study must be interpreted with some caution. It may be that the underlying relationship between masculine images of God and attitudes toward same-sex unions has shifted since 2007. Future research utilizing more recent data is necessary to continue to sort out exactly how religious gender traditionalism influences attitudes toward homosexuality and same-sex unions. 
This analysis confirms that there is a consistent and strong association between individuals' gendered images of God and their views toward same-sex civil unions and same-sex marriage. Those who view God as a "he" are signaling an underlying gendered view of reality that directs them to oppose relationships that contradict traditional gendered roles. Because gay unions cannot symbolize this gendered reality, they are deemed inappropriate. As attitudes in the wider culture continue to liberalize toward same-sex unions, we may find continued resistance from those who hold a gendered view of the divine. Just as though God can never be proven to not exist, God can also never be proven not to be masculine. This will allow some individuals to maintain their opposition toward same-sex unions because they draw their moral authority from this gendered cosmic source. This analysis also underscores the importance of accounting for both gender ideology and religion when analyzing attitudes toward same-sex unions.

Most importantly this finding urges future research to utilize measures that integrate separate social institutions, like gender and religion, as no social institution is completely separate from any other (Martin 2004). The gendered image of God measure accounts for a portion of the difference in attitudes toward same-sex unions that the gender traditionalism and religious belief measures utilized in past research were missing. Assessing the interconnectedness of religion with other social institutions will allow future analyses to account for distinctive segments of widely used concepts. This will also allow researchers of religion to be able to connect their work across various sub-fields of social scientific inquiry. 


\section{References}

Ammons, Samantha K. and Penny Edgell. 2007. Religious influences on work-family trade-offs. Journal of Family Issues 28: 794-826.

Andersen, Robert and Tina Fetner. 2008. Cohort differences in tolerance of homosexuality: Attitudinal change in Canada and the United States, 1981-2000. Public Opinion Quarterly 72(2):311-330.

Bader, Christopher D., Scott A. Desmond, F. Carson Mencken, and Byron R. Johnson. 2010. Divine justice: The relationship between images of God and attitudes toward criminal punishment. Criminal Justice Review 35:90-106.

Bang, Esther, M. Elizabeth Lewis Hall, Tamara L. Anderson, and Michele M. Willingham. 2005. Ethnicity, acculturation, and religiosity as predictors of female college students' role expectations. Sex Roles 53: 231-237.

Bartkowski, John P. 2001. Remaking the godly marriage: Gender negotiation in Evangelical families. New Brunswick: Rutgers University Press.

Bellah, Robert. 1975. The broken covenant: American civil religion in time of trial. New York, NY: Seabury Press.

Bem, Sandra L. 1993. The lenses of gender: Transforming the debate on sexual inequality. New Haven, CT: Yale University Press.

Berger, Peter L. 1967. The sacred canopy: Elements of a sociological theory of religion. New York, NY: Anchor Books.

Blashill, Aaron J. and Kimberly K. Powlishta. 2009. Gay stereotypes: The use of sexual orientation as a cue for gender-related attributes. Sex Roles 61:783-793.

Brewer, Paul R. and Clyde Wilcox. 2005. The polls - trends: Same-sex marriage and civil unions. Public Opinion Quarterly 69(4):599-616. 
Brumbaugh, Stacey M., Laura A. Sanchez, Steven L. Nock, and James D. Wright. 2008. Attitudes toward gay marriage in states undergoing marriage law transformation. Journal of Marriage and Family 70:345-359.

Burdette, Amy M., Christopher G. Ellison, and Terrence D. Hill. 2005. Conservative protestantism and tolerance toward homosexuals: An examination of potential mechanisms. Sociological Inquiry 75:177-196.

Christ, Carol P. 1987. Why women need the goddess. In Women's studies in religion: A multicultural reader, edited by Kate Bagley and John H. Evans, pp. 163-174: Upper Saddle River: Pearson Prentice Hall.

Daly, Mary. 1973. Beyond god the father: Toward a philosophy of women's liberation. Boston: Beacon Press.

Daly, Mary. 1985. The church and the second sex. Boston: Beacon Press.

Davis, Shannon N. and Theodore N. Greenstein. 2009. Gender ideology: Components, predictors, and consequences. Annual Review of Sociology 35:87-105.

Denton, Melinda Lundquist. 2004. Gender and marital decision making: Negotiating religious ideology and practice. Social Forces 82:1151-1180.

Dougherty, Kevin D., Byron R. Johnson, and Edward C. Polson. 2007. Recovering the lost: Remeasuring U.S. religious affiliation. Journal for the Scientific Study of Religion 46(4):483499.

Eskridge, William N., Jr. and Darren R. Spedale. 2006. Same-sex marriage: For better or worse?: What we've learned from the evidence. New York, NY: Oxford University Press.

Fetner, Tina. 2008. How the religious right shaped lesbian and gay activism. Minneapolis, MN: University of Minnesota Press.

Froese, Paul and Christopher D. Bader. 2007. God in America: Why theology is not simply the concern of philosophers. Journal for the Scientific Study of Religion 46:465-481. 
Froese, Paul and Christopher D. Bader. 2008. Unraveling religious worldviews: The relationship between images of god and political ideology in a cross-cultural analysis. The Sociological Quarterly 49:689-718.

Froese, Paul and Christopher D. Bader. 2010. America's four gods: What we say about god - and what that says about us. New York, NY: Oxford University Press.

Froese, Paul, Christopher D. Bader, and Buster Smith. 2008. Political tolerance and god's wrath in the United States. Sociology of Religion 69: 29-44.

Gallagher, Sally K. 2003. Evangelical identity and gendered family life. New Brunswick, NJ: Rutgers University Press.

Greeley, Andrew. 1988. Evidence that a maternal image of god correlates with liberal politics. Sociology and Social Research 72:150-154.

Greeley, Andrew. 1993. Religion and attitudes toward the environment. Journal for the Scientific Study of Religion 32:19-28.

Herek, Gregory M. 1986. On heterosexual masculinity. American Behavioral Scientist 29(5):563577.

Herek, Gregory M. 2002. Gender gaps in public opinion about lesbians and gay men. The Public Opinion Quarterly 66:40-66.

Hill, Terrence D., Benjamin E. Moulton, and Amy M. Burdette. 2004. Conservative protestantism and attitudes toward homosexuality: Does political orientation mediate this relationship? Sociological Focus 37:59-70.

Hoffmann, John P. and John P. Bartkowski. 2008. Gender, religious tradition and biblical literalism. Social Forces 86:1245-1272.

Kite, Mary E. and Bernard E. Whitley. 1996. Sex differences in attitudes toward homosexual persons, behaviors, and civil rights: A meta-analysis. Personality and Social Psychology Bulletin 22(4): 336-353. 
Kite, Mary E. and Bernard E. Whitley. 1998. Do heterosexual women and men differ in their attitudes toward homosexuality? A conceptual and methodological analysis. In Stigma and Sexual Orientation: Understanding Prejudice against Lesbians, Gay Men, and Bisexuals edited by G.M. Herek, pp. 39-61: Thousand Oaks, CA: Sage.

LaMar, Lisa and Mary Kite. 1998. Sex differences in attitudes toward gay men and lesbians: A multidimensional perspective. The Journal of Sex Research 35(2):189-196.

Lindsey, Linda L. 1990. Gender roles: A sociological perspective. Englewood Cliffs: Prentice Hall. Martin, Patricia Yancey. 2004. Gender as a social institution. Social Forces 82(4):1249-1273.

McVeigh, Rory and Maria-Elena D. Diaz. 2009. Voting to ban same-sex marriage: Interests, values, and communities. American Sociological Review 74:891-915.

Mencken, F. Carson, Christopher Bader, Elizabeth Embry. 2009. In god we trust: Images of god and trust in the United States among the highly religious. Sociological Perspectives 52: 23-38.

Morton, Nelle. 1985. The goddess as metaphoric image. In Women's studies in religion: A multicultural reader, edited by Kate Bagley and John H. Evans, pp. 192-197: Upper Saddle River: Pearson Prentice Hall.

New American Standard Bible. 1995. La Habra, CA: The Lockman Foundation.

Olson, Laura R., Wendy Cadge, and James T. Harrison. 2006. Religion and public opinion about same-sex marriage. Social Science Quarterly 87(2):340-360.

Ozorak, Elizabeth. 2003. Love of god and neighbor: Religion and volunteer service among college students. Review of Religious Research 44: 285-299.

Pampel, Fred C. 2000. Logistic regression: A primer. Thousand Oaks, CA: Sage Publications. Read, Jen'nan Ghazal and John P. Bartkowski. 2000. To veil or not to veil? A case study of identity negotiation among women in Austin, Texas. Gender and Society 14:295-417.

Rubin, Donald B. 1987. Multiple imputation for nonresponse in surveys. New York: Wiley. 
Rubin, Donald B. 1996. Multiple imputation after 18+ years. Journal of the American Statistical Association 91(434):473-489.

Sakalli, Nuray. 2002. The relationship between sexism and attitudes toward homosexuality in a sample of Turkish college students. Journal of Homosexuality 42(3):53-64.

Schieman, Scott. 2008. The religious role and the sense of personal control. Sociology of Religion 69(3):273-296.

Schieman, Scott, Alex Bierman, and Christopher G. Ellison. 2010. Religious involvement, beliefs about God, and the sense of mattering among older adults. Journal for the Scientific Study of Religion 49(3):517-535.

Schieman, Scott and Jong Hyun Jung. 2012. Practical divine influence: Socioeconomic status and belief in the prosperity gospel. Journal for the Scientific Study of Religion 51(4):738-756.

Sherkat, Darren E., Kylan Mattias de Vries, and Stacia Creek. 2010. Race, religion, and opposition to same-sex marriage. Social Science Quarterly 91(1): 80-98.

Sherkat, Darren E., Melissa Powell-Williams, Gregory Maddox, and Kylan Mattias de Vries. 2011. Religion, politics, and support for same-sex marriage in the United States, 1988-2008. Social Science Research 40: 167-180.

Silton, Nava R., Kevin J. Flannelly, Kathleen Galek, and Christopher G. Ellison. 2013. Beliefs about God and mental health among American adults. Journal of Religion and Health DOI: 10.1007/s10943-013-9712-3.

Sirin, Selcuk R., Donald R. McCreary, James R. Mahalik. 2004. Differential reactions to men and women's gender role transgressions: Perceptions of social status, sexual orientation, and value dissimilarity. The Journal of Men's Studies 12(2):119-132. 
Steensland, Brian, Jerry Z. Park, Mark D. Regnerus, Lynn D. Robinson, W. Bradford Wilcox, and Robert D. Woodberry. 2000. The measure of American religion: Toward improving the state of the art. Social Forces 79(1): 291-318.

Stone, Merlin. 1976. When god was a woman. New York: Harcourt Brace Jovanovich.

Stroope, Samuel, Scott Draper, and Andrew L. Whitehead. 2013. Images of a loving God and sense of meaning in life. Social Indicators Research 111:25-44.

Unnever, James D., Francis T. Cullen, and John P. Bartkowski. 2006. Images of God and public support for capital punishment: Does a close relationship with a loving God matter? Criminology 44(4):835-866.

Wald, Kenneth D., James W. Button, and Barbara A. Rienzo. 1996. The politics of gay rights in American communities: Explaining antidiscrimination ordinances and policies. American Journal of Political Science 40(4):1152-1178.

Wald, Kenneth D. and Allison Calhoun-Brown. 2007. Religion and politics in the United States. Lanham, MD: Rowman and Littlefield Publishers, Inc.

Whitehead, Andrew L. 2010. Sacred rites and civil rights: Religion's effect on attitudes toward samesex unions and the perceived cause of homosexuality. Social Science Quarterly 91:63-78.

Whitehead, Andrew L. 2012. Gender ideology and religion: Does a masculine image of God matter? Review of Religious Research 54:139-156.

Whitehead, Andrew L. 2013. Religious organizations and homosexuality: The acceptance of gays and lesbians in American congregations. Review of Religious Research 55:297-317.

Whitehead, Andrew L. and Joseph O. Baker. 2012. Homosexuality, religion, and science: Moral authority and the persistence of negative attitudes. Sociological Inquiry 82(4):487-509.

Whitley Jr., Bernard E. 2001. Gender-role variables and attitudes toward homosexuality. Sex Roles 45:691-721. 
Whitley, Bernard E. 2009. Religiosity and attitudes toward lesbians and gay men: A meta-analysis. The International Journal for the Psychology of Religion 19: 21-38.

Whitley Jr., Bernard E. and Stefanía Ægisdóttir. 2000. The gender belief system, authoritarianism, social dominance orientation, and heterosexuals' attitudes toward lesbians and gay men. Sex Roles 42:947-967. 
Table 1: Descriptive and Bivariate Statistics (MI Data)

\begin{tabular}{|c|c|c|c|c|c|}
\hline Variable & Description & $\begin{array}{l}\text { Mean } \\
\text { or } \%\end{array}$ & SD & $\begin{array}{l}\text { Correlation } \\
\text { w/ Civil } \\
\text { Unions }\end{array}$ & $\begin{array}{l}\text { Correlation } \\
\text { w/ Marriage }\end{array}$ \\
\hline $\begin{array}{l}\text { Agree to Same-Sex Civil } \\
\text { Unions }\end{array}$ & $\begin{array}{l}1=\text { Agree, Strongly } \\
\text { Agree }\end{array}$ & $55.9 \%$ & --- & --- & \\
\hline $\begin{array}{l}\text { Agree to Same-Sex } \\
\text { Marriage }\end{array}$ & $\begin{array}{l}1=\text { Agree, Strongly } \\
\text { Agree }\end{array}$ & $33.6 \%$ & --- & --- & \\
\hline View God as a "he" & $\begin{array}{l}1=\text { Strongly Disagree to } \\
5=\text { Strongly Agree }\end{array}$ & 3.35 & 1.32 & $-0.43 * * *$ & $-0.43 * * *$ \\
\hline Age & Age in years, 18 to 96 & 50.95 & 16.41 & $-0.06 *$ & $-0.14 * * *$ \\
\hline Female & $1=$ Female & $55.4 \%$ & --- & 0.02 & 0.05 \\
\hline White & $1=$ White & $94.8 \%$ & --- & $0.06^{*}$ & 0.04 \\
\hline South & $1=$ South & $30.9 \%$ & --- & $-0.16^{* * *}$ & $-0.12 * * *$ \\
\hline Married & $1=$ Married & $67.1 \%$ & --- & -0.02 & $-0.07 * *$ \\
\hline Income & $\begin{array}{l}1=\$ 10,000 \text { or less to } 7= \\
\$ 150,000 \text { or more }\end{array}$ & 4.42 & 1.49 & $0.22 * * *$ & $0.12 * * *$ \\
\hline Education & $\begin{array}{l}1=8^{\text {th }} \text { grade or less, } 7= \\
\text { postgraduate work/degree }\end{array}$ & 4.67 & 1.63 & $0.28 * * *$ & $0.18 * * *$ \\
\hline Politically Conservative & $\begin{array}{l}1=\text { Liberal to } 7= \\
\text { Conservative }\end{array}$ & 4.29 & 1.61 & $-0.41 * * *$ & $-0.59 * * *$ \\
\hline Homosexuality Innate & $1=$ Homosexuality Innate & $46.0 \%$ & --- & $0.50 * * *$ & $0.46 * * *$ \\
\hline $\begin{array}{l}\text { Traditional Gender-Role } \\
\text { Beliefs Index }(\alpha=0.74)\end{array}$ & $\begin{array}{l}\text { Summed index, } 4= \\
\text { Egalitarian to } 20= \\
\text { Conservative }\end{array}$ & 9.95 & 3.69 & $-0.49 * * *$ & $-0.46 * * *$ \\
\hline $\begin{array}{l}\text { View God as "Active" }(\alpha= \\
0.88)\end{array}$ & $\begin{array}{l}\text { Summed index, } 7=\text { Not } \\
\text { Active to } 35=\text { Very } \\
\text { Active }\end{array}$ & 26.51 & 6.72 & $-0.41 * * *$ & $-0.42 * * *$ \\
\hline $\begin{array}{l}\text { View God as "Angry" } \\
(\alpha=0.85)\end{array}$ & $\begin{array}{l}\text { Summed index, } 6=\text { Not } \\
\text { Angry to } 30=\text { Very } \\
\text { Angry }\end{array}$ & 16.55 & 6.28 & $-0.36 * * *$ & $-0.31 * * *$ \\
\hline Biblical Literalist & $1=$ Biblical literalist & $20.7 \%$ & --- & $-0.44 * * *$ & $-0.30 * * *$ \\
\hline $\begin{array}{l}\text { Religious Practice Index } \\
(\alpha=0.84)\end{array}$ & $\begin{array}{l}\text { Standardized and } \\
\text { summed index }-4=\text { least } \\
\text { involved to } 4=\text { most } \\
\text { involved }\end{array}$ & 0.00 & 2.60 & $-0.44 * * *$ & $-0.45 * * *$ \\
\hline Evangelical Protestant & $\begin{array}{l}1=\text { Evangelical } \\
\text { Protestant }\end{array}$ & $30.6 \%$ & --- & $-0.31 * * *$ & $-0.22 * * *$ \\
\hline Black Protestant & $1=$ Black Protestant & $3.7 \%$ & --- & $-0.08 * *$ & $-0.07 * *$ \\
\hline Mainline Protestant & $1=$ Mainline Protestant & $22.0 \%$ & --- & $0.09 * * *$ & 0.01 \\
\hline Catholic & $1=$ Catholic & $23.8 \%$ & --- & 0.04 & -0.04 \\
\hline Jewish & 1 = Jewish & $2.2 \%$ & --- & $0.12 * * *$ & $0.11 * * *$ \\
\hline Other & $1=$ Other & $6.4 \%$ & --- & $0.07 * *$ & $0.07 * *$ \\
\hline No Religion & $1=$ No Religion & $11.1 \%$ & --- & $0.22 * * *$ & $0.31 * * *$ \\
\hline
\end{tabular}

Source: BRS (2007)

$* \mathrm{p}<.05 ; * * \mathrm{p}<.01 ; * * * \mathrm{p}<.001$ 
Table 2: Logistic Regression Analysis of Favorable Attitudes toward Same-Sex Civil Unions on Masculine Images of God (MI Data)

\begin{tabular}{|c|c|c|c|c|c|c|c|c|c|c|}
\hline \multirow[b]{2}{*}{ Variables } & \multicolumn{2}{|c|}{ Model 1} & \multicolumn{2}{|c|}{ Model 2} & \multicolumn{2}{|c|}{ Model 3} & \multicolumn{2}{|c|}{ Model 4} & \multicolumn{2}{|c|}{ Model 5} \\
\hline & $\beta$ & OR & $\beta$ & OR & $\beta$ & OR & $\beta$ & OR & $\beta$ & OR \\
\hline \multicolumn{11}{|l|}{ Religion Controls } \\
\hline Biblical Literalist & $-0.23 * * *$ & 0.36 & $-0.23 * * *$ & 0.36 & $-0.21 * * *$ & 0.39 & $-0.23 * * *$ & 0.36 & $-0.21 * * *$ & 0.39 \\
\hline $\begin{array}{l}\text { Religious Practice } \\
\text { RELTRAD }^{a}\end{array}$ & $-0.18 * *$ & 0.88 & $-0.26 * * *$ & 0.84 & $-0.23 * * *$ & 0.85 & $-0.21 * * *$ & 0.86 & $-0.19 * *$ & 0.87 \\
\hline Black Protestant & -0.07 & --- & -0.09 & --- & -0.07 & --- & -0.08 & --- & -0.07 & --- \\
\hline Mainline Protestant & 0.02 & --- & 0.04 & --- & 0.03 & --- & 0.03 & --- & 0.02 & --- \\
\hline Catholic & -0.03 & --- & -0.02 & --- & -0.02 & --- & -0.03 & --- & -0.03 & --- \\
\hline Jewish & 0.08 & --- & 0.09 & --- & 0.08 & --- & 0.08 & --- & -0.07 & --- \\
\hline Other & 0.04 & --- & 0.06 & --- & 0.07 & --- & 0.05 & --- & 0.05 & --- \\
\hline No Religion & 0.03 & --- & 0.06 & --- & 0.04 & --- & 0.04 & --- & 0.02 & --- \\
\hline \multicolumn{11}{|l|}{ Socio-demographic Controls } \\
\hline Age & 0.02 & --- & 0.01 & --- & 0.02 & --- & 0.01 & --- & 0.02 & --- \\
\hline Female & 0.03 & --- & $0.08 *$ & 1.34 & 0.05 & --- & 0.07 & --- & 0.04 & --- \\
\hline White & -0.09 & --- & -0.12 & --- & -0.10 & --- & -0.12 & --- & -0.10 & --- \\
\hline South & $-0.09 *$ & 0.71 & $-0.11 * *$ & 0.65 & $-0.10 *$ & 0.69 & -0.11 & --- & $-0.09 *$ & 0.70 \\
\hline Married & -0.03 & --- & -0.03 & --- & -0.03 & --- & -0.03 & --- & -0.03 & --- \\
\hline Income & $0.14 * *$ & 1.18 & $0.17 * * *$ & 1.23 & $0.15 * *$ & 1.20 & $0.16^{* * *}$ & 1.21 & $0.14 * *$ & 1.19 \\
\hline Education & $0.22 * * *$ & 1.28 & $0.22 * * *$ & 1.28 & $0.21 * * *$ & 1.27 & $0.21 * * *$ & 1.27 & $0.21 * * *$ & 1.26 \\
\hline Politically Conservative & $-0.16^{* * *}$ & 0.84 & $-0.18 * * *$ & 0.82 & $-0.14 * *$ & 0.85 & $-0.17 * * *$ & 0.83 & $-0.13 * *$ & 0.86 \\
\hline Homosexuality Innate & $0.38 * * *$ & 3.97 & $0.40 * * *$ & 4.30 & $0.38 * * *$ & 3.99 & $0.40 * * *$ & 4.33 & $0.38 * * *$ & 4.02 \\
\hline \multicolumn{11}{|l|}{ Key Control Variables } \\
\hline Trad. Gender-Role Beliefs & $-0.25 * * *$ & 0.87 & --- & --- & $-0.23 * * *$ & 0.89 & --- & --- & $-0.22 * * *$ & 0.90 \\
\hline "Active" God & -0.10 & --- & --- & --- & --- & --- & -0.06 & --- & -0.05 & --- \\
\hline “Angry” God & $-0.11 *$ & 0.97 & --- & --- & --- & --- & $-0.10^{*}$ & 0.97 & -0.08 & --- \\
\hline \multicolumn{11}{|l|}{ Masculine Image of God } \\
\hline God is a "he" & --- & --- & $-0.23 * * *$ & 0.73 & $-0.19 * * *$ & 0.77 & $-0.19 * * *$ & 0.77 & $-0.16 * *$ & 0.81 \\
\hline Intercept & $1.94 *$ & & 0.61 & & 1.36 & & 1.47 & & $2.08 *$ & \\
\hline $\mathrm{N}$ & 1,648 & & 1,648 & & 1,648 & & 1,648 & & 1,648 & \\
\hline PRE & 0.368 & & 0.358 & & 0.370 & & 0.362 & & 0.372 & \\
\hline
\end{tabular}

$* \mathrm{p}<.05 ; * * \mathrm{p}<.01 ; * * * \mathrm{p}<.001 ;$ two-tailed significance tests

$\beta=$ Standardized Coefficient

OR = Odds Ratio

${ }^{\mathrm{a}}$ Evangelical Protestant is contrast category 
Table 3: Logistic Regression Analysis of Favorable Attitudes toward Same-Sex Marriage on Masculine Images of God (MI Data)

\begin{tabular}{|c|c|c|c|c|c|c|c|c|c|c|}
\hline \multirow[b]{2}{*}{ Variables } & \multicolumn{2}{|c|}{ Model 1} & \multicolumn{2}{|c|}{ Model 2} & \multicolumn{2}{|c|}{ Model 3} & \multicolumn{2}{|c|}{ Model 4} & \multicolumn{2}{|c|}{ Model 5} \\
\hline & $\beta$ & OR & $\beta$ & OR & $\beta$ & OR & $\beta$ & OR & $\beta$ & OR \\
\hline \multicolumn{11}{|l|}{ Religion Controls } \\
\hline Biblical Literalist & $-0.14^{*}$ & 0.54 & -0.13 & --- & -0.11 & --- & -0.13 & --- & -0.11 & --- \\
\hline $\begin{array}{l}\text { Religious Practice } \\
\text { RELTRAD }^{\mathrm{a}}\end{array}$ & $-0.26^{* * * *}$ & 0.83 & $-0.31 * * *$ & 0.81 & $-0.29 * * *$ & 0.82 & $-0.30 * * *$ & 0.81 & $-0.29 * * *$ & 0.82 \\
\hline Black Protestant & -0.13 & --- & -0.13 & --- & -0.13 & --- & -0.13 & --- & -0.13 & --- \\
\hline Mainline Protestant & 0.03 & --- & -0.01 & --- & -0.03 & --- & -0.01 & --- & -0.03 & --- \\
\hline Catholic & -0.09 & --- & -0.08 & --- & -0.09 & --- & -0.08 & --- & -0.09 & --- \\
\hline Jewish & 0.03 & --- & 0.04 & --- & 0.03 & --- & 0.04 & --- & 0.03 & --- \\
\hline Other & 0.02 & --- & 0.02 & --- & 0.02 & --- & 0.02 & --- & 0.02 & --- \\
\hline No Religion & 0.07 & --- & 0.08 & --- & 0.05 & --- & 0.07 & --- & 0.05 & --- \\
\hline \multicolumn{11}{|l|}{ Socio-demographic Controls } \\
\hline Age & $-0.09 *$ & 0.99 & $-0.11^{*}$ & 0.99 & $-0.10^{*}$ & 0.99 & $-0.11^{*}$ & 0.99 & $-0.10^{*}$ & 0.99 \\
\hline Female & 0.04 & --- & $0.08 *$ & 1.35 & 0.05 & --- & 0.08 & --- & 0.05 & --- \\
\hline White & -0.08 & --- & -0.10 & --- & -0.09 & --- & -0.10 & --- & -0.09 & --- \\
\hline South & -0.05 & --- & -0.06 & --- & -0.05 & --- & -0.06 & --- & -0.05 & --- \\
\hline Married & -0.05 & --- & -0.04 & --- & -0.04 & --- & -0.04 & --- & -0.04 & --- \\
\hline Income & 0.08 & --- & $0.11^{*}$ & 1.14 & 0.09 & --- & $0.11 *$ & 1.14 & 0.09 & --- \\
\hline Education & 0.03 & --- & 0.01 & --- & 0.01 & --- & 0.01 & --- & 0.01 & --- \\
\hline Politically Conservative & $-0.54 * * *$ & 0.55 & $-0.54 * * *$ & 0.54 & $-0.52 * * *$ & 0.56 & $-0.54 * * *$ & 0.54 & $-0.52 * * *$ & 0.56 \\
\hline Homosexuality Innate & $0.34 * * *$ & 3.48 & $0.36 * * *$ & 3.77 & $0.35^{* * *}$ & 3.55 & $0.36^{* * *}$ & 3.77 & $0.35^{* * *}$ & 3.55 \\
\hline \multicolumn{11}{|l|}{ Key Control Variables } \\
\hline Trad. Gender-Role Beliefs & $-0.23 * * *$ & 0.89 & --- & --- & $-0.20 * * *$ & 0.91 & --- & --- & $-0.20 * * *$ & 0.91 \\
\hline "Active" God & -0.06 & --- & --- & --- & --- & --- & -0.01 & --- & -0.00 & --- \\
\hline "Angry" God & -0.04 & --- & --- & --- & --- & --- & -0.01 & --- & -0.00 & --- \\
\hline \multicolumn{11}{|l|}{ Masculine Image of God } \\
\hline God is a "he" & --- & --- & $-0.22 * * *$ & 0.74 & $-0.18 * *$ & 0.78 & $-0.21 * * *$ & 0.75 & $-0.18 * *$ & 0.78 \\
\hline Intercept & $3.43 * * *$ & & $2.69 * * *$ & & $3.48 * * *$ & & $2.80 * *$ & & $3.48 * * *$ & \\
\hline $\mathrm{N}$ & 1,648 & & 1,648 & & 1,648 & & 1,648 & & 1,648 & \\
\hline PRE & 0.400 & & 0.398 & & 0.406 & & 0.398 & & 0.406 & \\
\hline
\end{tabular}

$* \mathrm{p}<.05 ; * * \mathrm{p}<.01 ; * * * \mathrm{p}<.001 ;$ two-tailed significance tests

$\beta=$ Standardized Coefficient

OR = Odds Ratio

${ }^{a}$ Evangelical Protestant is contrast category 
Figure 1: Predicted Probabilities for Support of Same-Sex Civil Unions and Marriage by Masculine Image of God

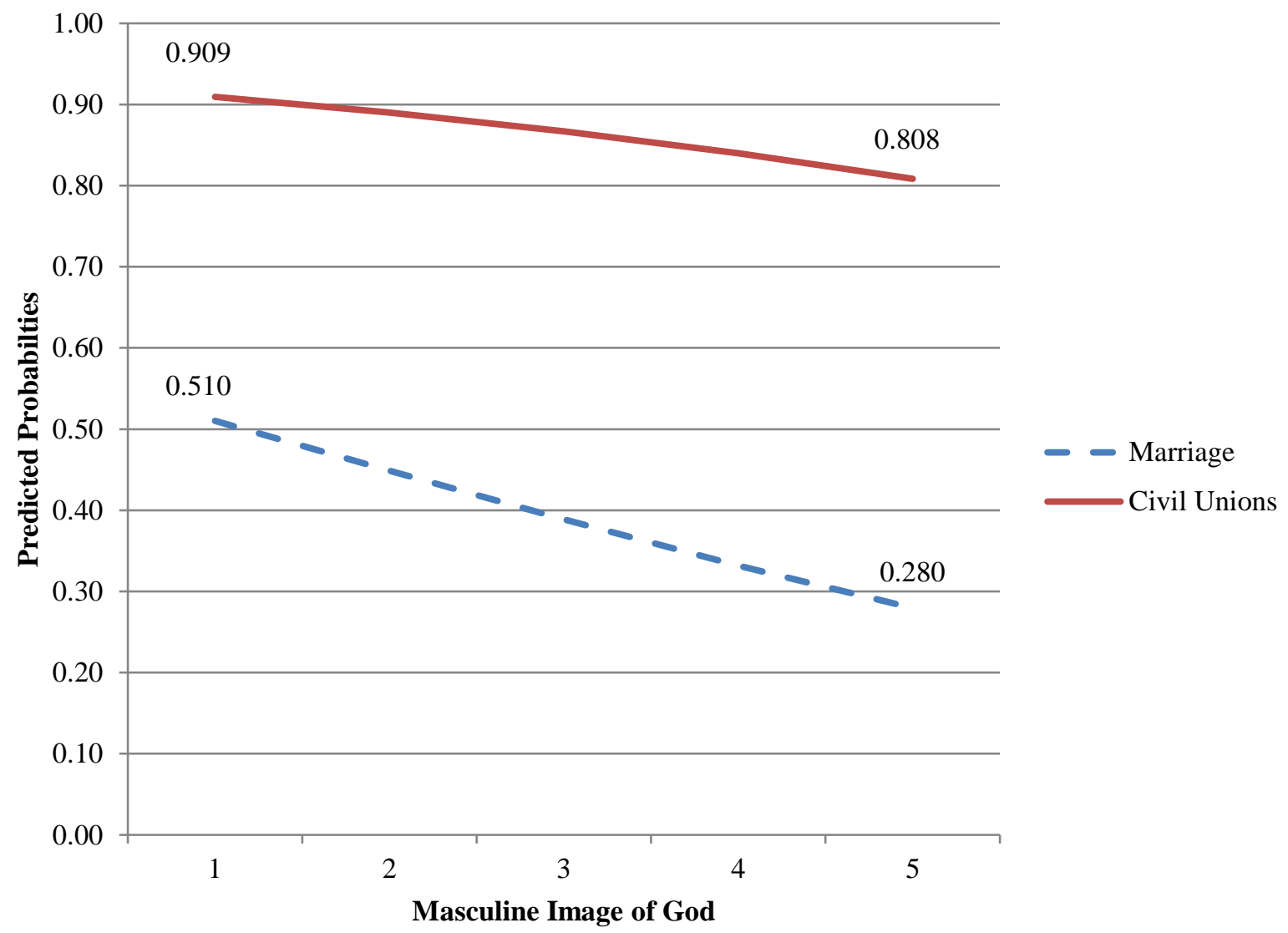

